\title{
Desertibacter roseus gen. nov., sp. nov., a gamma radiation-resistant bacterium in the family Rhodospirillaceae, isolated from desert sand
}

Correspondence
Chengxiang Fang
cxfang@whu.edu.cn

\author{
Ming Liu, ${ }^{1}$ Jun Dai, ${ }^{1}$ Yufeng Liu, ${ }^{1}$ Feng Cai, ${ }^{1}$ Yaqiong Wang, ${ }^{1}$ \\ Erkin Rahman ${ }^{2}$ and Chengxiang Fang ${ }^{1}$ \\ ${ }^{1}$ College of Life Sciences, Wuhan University, Wuhan 430072, PR China \\ ${ }^{2}$ College of Life Sciences and Technology, Xinjiang University, Urumchi 830046, PR China
}

At the time of writing, the family Rhodospirillaceae encompassed 26 genera (http://www.bacterio.cict.fr/classif generafamilies.html\#Rhodospirillaceae) including bacteria isolated from, for example, marine habitats, freshwater, activated sludge biomass, air, soil, the rhizosphere and deserts (Mack et al., 1993; Pfennig et al., 1997; López-López et al., 2002; Garrity et al., 2005; Liu et al., 2007; Weon et al., 2007; Yoon et al., 2007; Kodama et al., 2008; Zhang et al., 2008; An et al., 2009). None, however, has been reported to withstand gamma radiation (Cox \& Battista, 2005). Radiation-resistant bacteria can survive severe damage from gamma radiation, which implies that they have high DNA repair efficiency (Sghaier et al., 2008) and are adept at detoxifying reactive oxygen species (ROS) (Zhang et al., 2007). It is widely acknowledged that carotenoids play beneficial roles in scavenging electrons from ROS and, because of the close link between ROS and various diseases, there is continuing interest in finding antioxidants, particularly carotenoids, that can act as preventive or therapeutic drugs. Therefore, in an attempt to explore novel radiation-resistant bacteria, numerous bacteria were isolated from the Taklimakan desert, Xinjiang, China, as there is known to be a close link between desiccation and

Abbreviations: $\mathrm{PHB}$, poly- $\beta$-hydroxybutyrate; ROS, reactive oxygen species.

The GenBank/EMBL/DDBJ accession number for the 16S rRNA gene sequence of strain $2622^{\top}$ is EU833987.

Two supplementary tables are available with the online version of this paper. radiation resistance (Fredrickson et al., 2008; Mattimore \& Battista, 1996). A pink-pigmented bacterial strain was isolated, designated $2622^{\mathrm{T}}$, belonging to the family Rhodospirillaceae. The aim of the present study was to determine the exact taxonomic position of this strain, which was isolated from a gamma-irradiated sand sample.

Sand was sampled from the desert, and $1 \mathrm{~g}$ samples were exposed to $10 \mathrm{kGy}$ radiation at a dose of $300 \mathrm{~Gy} \mathrm{~min}^{-1}$ at room temperature. After exposure, the samples were serially diluted in water $(0.85 \%, \mathrm{w} / \mathrm{v}, \mathrm{NaCl})$ and plated on different media: tenfold-diluted trypticase soy agar $(0.1 \times$ TSA; Difco), twofold-diluted trypticase soy agar $(0.5 \times$ TSA; Difco), twofold-diluted R2A agar (0.5 × R2A; Difco), PTYG agar (Fredrickson et al., 2008), nutrient agar (Difco) and R2A agar (Difco). After incubation at $30^{\circ} \mathrm{C}$ for 20 days, single colonies on the plates were purified. Strain $2622^{\mathrm{T}}$ was isolated on R2A agar and stored by lyophilization.

Genomic DNA extraction and amplification of the $16 \mathrm{~S}$ rRNA gene of strain $2622^{\mathrm{T}}$ were carried out as described by Rainey et al. (1996); PCR products were sequenced by Invitrogen Biotechnology Co. Ltd. Similarity searches with reference sequences were performed with the EzTaxon database (Chun et al., 2007). Phylogenetic analysis was performed by using MEGA version 4.0 (Tamura et al., 2007), after multiple alignment of the data via CLUSTAL $\mathrm{X}$ (Thompson et al., 1997). Distances were obtained by using options according to Kimura's two-parameter model (Kimura, 1980) and clustering was performed by using the neighbour-joining and maximum-parsimony methods 
(Saitou \& Nei, 1987). The topologies of the neighbourjoining and maximum-parsimony phylogenetic trees were evaluated by using bootstrap resampling (Felsenstein, 1985) with 1000 replications (Fig. 1 and Supplementary Fig. S1, available in IJSEM Online).

Cell morphology was examined by phase-contrast microscopy (Olympus) and by transmission electron microscopy. A number of key characteristics identified via standard procedures (Gerhardt et al., 1994) were also tested: $\mathrm{KOH}$ string test (Gram stain), oxidase, catalase (3\% $\mathrm{H}_{2} \mathrm{O}_{2}$ ), nitrate reduction and hydrolysis of aesculin, casein, tyrosine, starch and gelatin. Poly- $\beta$-hydroxybutyrate (PHB) accumulation was observed by light microscopy after staining the cells with Sudan black (Smibert \& Krieg, 1994). Growth at $4,12,18,25,30,37,42$ and $45^{\circ} \mathrm{C}$ and with $0,0.5,1.0,1.5$ and $2.0 \% \mathrm{NaCl}$ was tested on $\mathrm{R} 2 \mathrm{~A}$ agar; growth at $\mathrm{pH}$ 6-11 (at intervals of $1 \mathrm{pH}$ unit) was determined in R2A broth. Anaerobic growth was assessed on R2A agar (both with and without $\mathrm{KNO}_{3}$ ) incubated in air-tight jars containing an AnaeroPack (Oxoid). In addition, NFb and M media (Eckert et al., 2001; Xie \& Yokota, 2005) were used for assays of acetylene reduction, which were carried out as described by Mehnaz \& Lazarovits (2006). Bacteriochlorophyll a content was determined as described by Biebl et al. (2005). Antibiotic resistance was determined with the disc diffusion method (Buczolits et al., 2002) on R2A agar incubated for up to 3 days at $30^{\circ} \mathrm{C}$. Strain $2622^{\mathrm{T}}$ was also characterized by using the whole test spectra of the API ZYM, API 20NE and API 20E systems (bioMérieux) according to the manufacturer's instructions.

To investigate the chemotaxonomic characteristics of strain $2622^{\mathrm{T}}$, it was grown on $\mathrm{R} 2 \mathrm{~A}$ agar at $30{ }^{\circ} \mathrm{C}$ for 3 days. Determination of whole-cell fatty acid profiles and analysis of fatty acid methyl esters were carried out according to the standard protocol of the Sherlock Microbial Identification System (MIDI). Respiratory quinones were analysed according to the protocol of Xie \& Yokota (2003). DNA was extracted from cells grown in R2A broth by using a modified version of the method described by Wilson (1987). The HPLC method of Mesbah et al. (1989) was used to determine the $\mathrm{G}+\mathrm{C}$ content of the extracted DNA.

Phylogenetic analysis of the 16S rRNA gene sequence of strain $2622^{\mathrm{T}}$ showed that it formed a distinct lineage within the family Rhodospirillaceae (Fig. 1). The nearest phylogenetic neighbours of strain $2622^{\mathrm{T}}$ were species of the genus Skermanella; strain $2622^{\mathrm{T}}$ shared 91.7 and $90.1 \% 16 \mathrm{~S}$ rRNA gene sequence similarity with the type strains of Skermanella xinjiangensis and Skermanella aerolata, respectively, $89.8-88.1 \%$ similarity with the type strains of species in the genus Azospirillum and $84.5-89.5 \%$ with the type strains of other type species of the family Rhodospirillaceae. In the neighbour-joining phylogenetic tree, strain $2622^{\mathrm{T}}$ clearly formed a basal branch of the sister clade containing Skermanella parooensis ACM $2042^{\mathrm{T}}$; nonetheless, it formed a distinct line which was clearly separated from the genus Skermanella.

More importantly, strain $2622^{\mathrm{T}}$ could be differentiated from members of the family Rhodospirillaceae based on chemotaxonomic characteristics. The cellular fatty acid profile of strain $2622^{\mathrm{T}}$ included $\mathrm{C}_{18: 1} \omega 7 c(49.8 \%), \mathrm{C}_{16: 0}$ (11.1\%), $\mathrm{C}_{18: 0}(9.3 \%)$, summed feature 3 (iso- $\mathrm{C}_{15: 0} 2-\mathrm{OH}$ and/or $\left.\mathrm{C}_{16: 1} \omega 7 c, 8.6 \%\right), \mathrm{C}_{16: 1} \omega 5 c \quad(5.6 \%), \mathrm{C}_{18: 1} \omega 9 c$ $(4.1 \%)$, summed feature $2\left(\mathrm{C}_{14: 0} 3-\mathrm{OH}\right.$ and/or iso- $\mathrm{C}_{16: 1}$ I, $2.9 \%)$ and $\mathrm{C}_{16: 0} 3-\mathrm{OH}(1.1 \%)$. Although $\mathrm{C}_{18: 1} \omega 7 c$ was commonly found as a major component in members of the family Rhodospirillaceae (Choi et al., 2009; Díaz-Cárdenas et al., 2010; Lakshmi et al., 2011; Lai et al., 2009a, b; Liu et al., 2010; Urios et al., 2008; Wang et al., 2009; Zhang et al., 2008), significant amounts of $\mathrm{C}_{16: 1} \omega 5 c$ and $\mathrm{C}_{18: 0}$

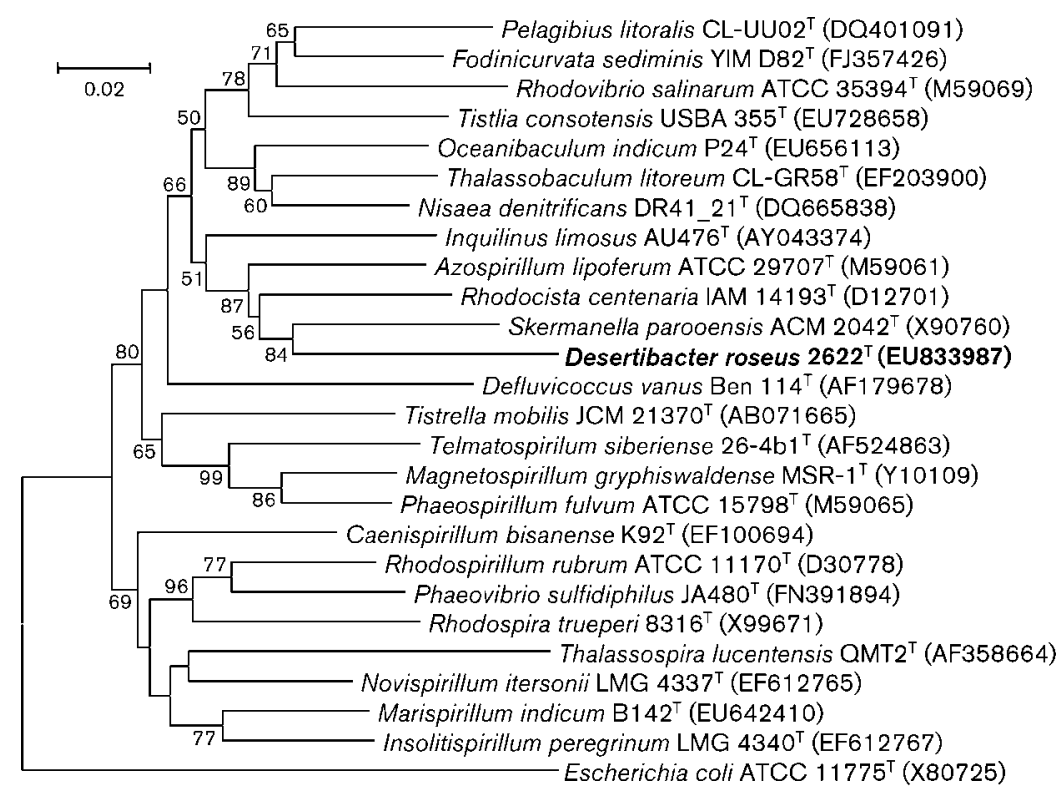

Fig. 1. Neighbour-joining tree based on $16 \mathrm{~S}$ rRNA gene sequences, showing the phylogenetic relationship between strain $2622^{\top}$ and related taxa. Bootstrap values (expressed as percentages of 1000 replications) $\geqslant 50 \%$ are given at nodes. Bar, 0.02 substitutions per nucleotide position. The sequence of Escherichia coli ATCC $11775^{\top}$ was used as an outgroup. 
3-OH were found in strain $2622^{\mathrm{T}}$ only, and not in Azospirillum lipoferum ATCC $29707^{\mathrm{T}}$ or S. parooensis DSM $9257^{\mathrm{T}}$ (Table 1). Moreover, the sole isoprenoid quinone in strain $2622^{\mathrm{T}}$ was ubiquinone $10(\mathrm{Q}-10)$, which is also found in the genera Skermanella and Azospirillum; however, in S. parooensis DSM $9257^{\mathrm{T}}$ and A. lipoferum ATCC $29707^{\mathrm{T}}$, small amounts of menaquinone 8 (MK-8; $20.9 \%)$ and Q-9 (4.5\%), respectively, were also found (Table 2).

Cells of strain $2622^{\mathrm{T}}$ were strictly aerobic, Gram-negative rods that were motile by means of a single polar flagellum (Supplementary Fig. S2). PHB granules were also detected. Colonies were pink, circular and convex with regular margins after growth on R2A agar at $37{ }^{\circ} \mathrm{C}$ for 4 days. Growth was observed at $12-42{ }^{\circ} \mathrm{C}$, with good growth between 37 and $40{ }^{\circ} \mathrm{C}$. Growth was observed with $0-1.5 \%$ $\mathrm{NaCl}$ (optimum $0.5 \% \mathrm{NaCl}$ ) and at $\mathrm{pH} \mathrm{7-10} \mathrm{(optimum}$ $\mathrm{pH}$ 8). Strain $2622^{\mathrm{T}}$ was unable to reduce acetylene in either $\mathrm{NFb}$ or M media and was unable to fix nitrogen. This latter characteristic can be used to distinguish strain $2622^{\mathrm{T}}$ from species of the genus Azospirillum. Strain $2622^{\mathrm{T}}$ was positive for oxidase, catalase and nitrate reductase. Aesculin and gelatin were hydrolysed, but casein, tyrosine and starch were not. The results of API ZYM, API 20E, API $20 \mathrm{NE}$ and antibiotic susceptibility tests are detailed in the species description.

Strain $2622^{\mathrm{T}}$ is phylogenetically closely related to the genera Skermanella and Azospirillum (Fig. 1). The lack of strong clustering, however, suggested that strain $2622^{\mathrm{T}}$ belonged to

Table 1. Cellular fatty acid profiles of strain $2622^{\top}$ and the type strains of phylogenetically related type species of the family Rhodospirillaceae

Strains: 1, 2622 ${ }^{\mathrm{T}}$; 2, Azospirillum lipoferum ATCC $29707^{\mathrm{T}}$; 3, Skermanella parooensis DSM $9257^{\mathrm{T}}$. All data were obtained in this study. A. lipoferum ATCC $29707^{\mathrm{T}}$ and S. parooensis DSM $9257^{\mathrm{T}}$ were grown on R2A agar (Difco) at $30{ }^{\circ} \mathrm{C}$ for 3 days. -, Not detected or $<1 \%$.

\begin{tabular}{|lccc|}
\hline Fatty acid & $\mathbf{1}$ & $\mathbf{2}$ & $\mathbf{3}$ \\
\hline $\mathrm{C}_{18: 1} \omega 7 c$ & 49.8 & 39.1 & 42.5 \\
$\mathrm{C}_{16: 0}$ & 11.1 & 15.0 & 25.6 \\
$\mathrm{C}_{18: 0}$ & 9.3 & 6.0 & 8.8 \\
$\mathrm{C}_{16: 1} \omega 5 c$ & 5.6 & - & - \\
$\mathrm{C}_{18: 1} \omega 9 c$ & 4.1 & 2.2 & 3.5 \\
$\mathrm{C}_{18: 0} 3-\mathrm{OH}$ & 1.5 & - & - \\
$\mathrm{C}_{16: 0} 3-\mathrm{OH}$ & 1.1 & 2.0 & 3.0 \\
$\mathrm{C}_{17: 1} \omega 6 c$ & 1.0 & 9.4 & - \\
Summed feature $3^{*}$ & 8.6 & 3.1 & 5.5 \\
Summed feature $2^{*}$ & 2.8 & 3.8 & 4.8 \\
\end{tabular}

*Summed features are groups of two or three fatty acids that cannot be separated by GLC with the MIDI System. Summed feature 3 comprised iso- $\mathrm{C}_{15: 0}$ 2-OH and/or $\mathrm{C}_{16: 1} \omega 7 c$; summed feature 2 comprised $\mathrm{C}_{14: 0} 3-\mathrm{OH}$ and/or iso- $\mathrm{C}_{16: 1} \mathrm{I}$.
Table 2. Characteristics that separate strain $2622^{\top}$ from phylogenetically related members of the family Rhodospirillaceae

Strains: 1, 2622 $2^{\mathrm{T}}$; 2, Azospirillum lipoferum ATCC $29707^{\mathrm{T}}$; 3, Skermanella parooensis DSM $9257^{\mathrm{T}}$. Data were obtained in this study unless indicated.

\begin{tabular}{|c|c|c|c|}
\hline Characteristic & 1 & 2 & 3 \\
\hline Colony colour & Pink & White & Pale pink \\
\hline Cell shape & Rod & Vibrioid & Rod \\
\hline $\begin{array}{l}\text { Maximum growth temperature } \\
\left({ }^{\circ} \mathrm{C}\right)\end{array}$ & 42 & 40 & 37 \\
\hline $\mathrm{pH}$ range & $7-10$ & $6-7$ & $6-9$ \\
\hline Tolerance of $2 \% \mathrm{NaCl}$ & - & + & + \\
\hline \multicolumn{4}{|l|}{ Assimilation of carbon sources } \\
\hline $\mathrm{N}$-Acetylglucosamine & - & + & - \\
\hline L-Arabinose & - & + & + \\
\hline D-Glucose & - & + & + \\
\hline D-Mannose & - & + & + \\
\hline D-Mannitol & - & + & + \\
\hline \multicolumn{4}{|l|}{ Enzyme activities } \\
\hline Gelatinase & + & - & - \\
\hline Cystine arylamidase & + & - & - \\
\hline Acid phosphatase & - & + & + \\
\hline Major quinone(s) & Q-10 & Q-10, Q-9 & Q-10, MK-8 \\
\hline DNA G $+\mathrm{C}$ content $(\mathrm{mol} \%)$ & 71.4 & $69-70^{a_{\star}}$ & $66.4-68.0^{b}$ \\
\hline
\end{tabular}

${ }^{\star}$ Data for the species from: $a$, Tarrand et al. (1978); b, Sly \& Stackebrandt (1999).

a new genus, which was supported by physiological features, fatty acid profile and quinone composition. Based on the phenotypic, chemotaxonomic and phylogenetic data presented, we therefore suggest that strain $2622^{\mathrm{T}}$ represents a novel species of a new genus, for which the name Desertibacter roseus gen. nov., sp. nov. is proposed.

\section{Description of Desertibacter gen. nov.}

Desertibacter (De.ser.ti.bac'ter. L. n. desertum desert; N.L. masc. n. bacter rod; N.L. masc. n. Desertibacter a desert bacterium).

Cells are Gram-negative rods, motile by means of a single polar flagellum and strictly aerobic. Catalase- and oxidasepositive. Nitrate is reduced to nitrite. Unable to fix nitrogen. Bacteriochlorophyll $a$ is not detected. The isoprenoid quinone is Q-10. The main cellular fatty acids are $\mathrm{C}_{18: 1} \omega 7 c, \mathrm{C}_{16: 0}, \mathrm{C}_{18: 0}$, summed feature 3 (iso- $\mathrm{C}_{15: 0}$ 2-OH and/or $\mathrm{C}_{16: 1} \omega 7 c$ ) and $\mathrm{C}_{16: 1} \omega 5 c$. On the basis of $16 \mathrm{~S}$ rRNA gene sequence analysis, the genus belongs to the family Rhodospirillaceae. The type species is Desertibacter roseus.

\section{Description of Desertibacter roseus sp. nov.}

Desertibacter roseus (ro'se.us. L. masc. adj. roseus rosecoloured, pink). 
Displays the following properties in addition to those given in the genus description. Colonies are pink, circular and convex with regular margins. Cells contain PHB. Growth occurs at $12-42{ }^{\circ} \mathrm{C}$ (optimum $37-40{ }^{\circ} \mathrm{C}$ ), at $\mathrm{pH} 7-10$ (optimum $\mathrm{pH} 8$ ) and at $\mathrm{NaCl}$ concentrations of up to $1.5 \%$ (optimum $0.5 \% \mathrm{NaCl}$ ). Hydrolyses aesculin and gelatin but not casein, tyrosine or starch. In API ZYM tests, positive for alkaline phosphatase, esterase (C4), esterase lipase (C8), leucine arylamidase, valine arylamidase, cystine arylamidase, naphthol-AS-BI-phosphohydrolase, $\beta$-galactosidase (weakly) and $\alpha$-glucosidase (weakly) and negative for lipase (C14), trypsin, $\alpha$-chymotrypsin, acid phosphatase, $\alpha$-galactosidase, $\beta$-glucuronidase, $N$-acetyl- $\beta$-glucosaminidase, $\beta$-glucosidase, $\alpha$-mannosidase and $\alpha$-fucosidase. In API 20NE tests, shows positive reactions for nitrate reduction, aesculin hydrolysis, gelatin hydrolysis, urease and $\beta$-galactosidase and negative reactions for arginine dihydrolase, indole production and glucose fermentation. Does not assimilate D-glucose, L-arabinose, maltose, D-mannose, D-mannitol, $\mathrm{N}$-acetylglucosamine, adipic acid, capric acid, malic acid, potassium gluconate, trisodium citrate or phenylacetic acid. In API 20E tests, shows positive reactions for $\beta$-galactosidase, Voges-Proskauer reaction, urease and gelatin hydrolysis, but negative reactions for arginine dihydrolase, lysine decarboxylase, ornithine decarboxylase, citrate utilization, $\mathrm{H}_{2} \mathrm{~S}$ production, tryptophan deaminase, indole production and oxidation of glucose, mannitol, inositol, sorbitol, rhamnose, sucrose, melibiose, amygdalin and arabinose. Susceptible to (per disc) erythromycin $(15 \mu \mathrm{g})$, vancomycin $(30 \mu \mathrm{g})$, streptomycin $(10 \mu \mathrm{g})$, acheomycin $(30 \mu \mathrm{g})$ and penicillin (10 IU). The DNA G + C content of the type strain is $71.4 \mathrm{~mol} \%$.

The type strain, $2622^{\mathrm{T}}$ (=CCTCC AB $208152^{\mathrm{T}}=$ KCTC $22436^{\mathrm{T}}$ ), was isolated from sand from the Taklimakan desert in Xinjiang, China.

\section{Acknowledgements}

This work was supported by the R \& D Infrastructure and Facility Development Program from the Ministry of Science and Technology of the People's Republic of China (Grant 203 no. 2005DKA21208). We also thank $\mathrm{Mr}$ James Swezey from NRRL for providing Azospirillum lipoferum ATCC $29707^{\mathrm{T}}$.

\section{References}

An, H., Zhang, L., Tang, Y., Luo, X., Sun, T., Li, Y., Wang, Y., Dai, J. \& Fang, C. (2009). Skermanella xinjiangensis sp. nov., isolated from the desert of Xinjiang, China. Int J Syst Evol Microbiol 59, 15311534 .

Biebl, H., Allgaier, M., Tindall, B. J., Koblizek, M., Lünsdorf, H., Pukall, R. \& Wagner-Döbler, I. (2005). Dinoroseobacter shibae gen. nov., sp. nov., a new aerobic phototrophic bacterium isolated from dinoflagellates. Int $J$ Syst Evol Microbiol 55, 1089-1096.

Buczolits, S., Denner, E. B. M., Vybiral, D., Wieser, M., Kämpfer, P. \& Busse, H. J. (2002). Classification of three airborne bacteria and proposal of Hymenobacter aerophilus sp. nov. Int J Syst Evol Microbiol 52, 445-456.
Choi, D. H., Hwang, C. Y. \& Cho, B. C. (2009). Pelagibius litoralis gen. nov., sp. nov., a marine bacterium in the family Rhodospirillaceae isolated from coastal seawater. Int J Syst Evol Microbiol 59, 818823.

Chun, J., Lee, J. H., Jung, Y., Kim, M., Kim, S., Kim, B. K. \& Lim, Y. W. (2007). EzTaxon: a web-based tool for the identification of prokaryotes based on $16 \mathrm{~S}$ ribosomal RNA gene sequences. Int J Syst Evol Microbiol 57, 2259-2261.

Cox, M. M. \& Battista, J. R. (2005). Deinococcus radiodurans - the consummate survivor. Nat Rev Microbiol 3, 882-892.

Díaz-Cárdenas, C., Patel, B. K. \& Baena, S. (2010). Tistlia consotensis gen. nov., sp. nov., an aerobic, chemoheterotrophic, free-living, nitrogen-fixing alphaproteobacterium, isolated from a Colombian saline spring. Int J Syst Evol Microbiol 60, 1437-1443.

Eckert, B., Weber, O. B., Kirchhof, G., Halbritter, A., Stoffels, M. \& Hartmann, A. (2001). Azospirillum doebereinerae sp. nov., a nitrogenfixing bacterium associated with the $\mathrm{C}_{4}$-grass Miscanthus. Int J Syst Evol Microbiol 51, 17-26.

Felsenstein, J. (1985). Confidence limits on phylogenies: an approach using the bootstrap. Evolution 39, 783-791.

Fredrickson, J. K., Li, S. M., Gaidamakova, E. K., Matrosova, V. Y., Zhai, M., Sulloway, H. M., Scholten, J. C., Brown, M. G., Balkwill, D. L. \& Daly, M. J. (2008). Protein oxidation: key to bacterial desiccation resistance? ISME J 2, 393-403.

Garrity, G. M., Bell, J. A. \& Lilburn, T. (2005). Family I. Rhodospirillaceae Pfennig and Trüper 1971, 17 ${ }^{\mathrm{AL}}$. In Bergey's Manual of Systematic Bacteriology, 2nd edn, vol. 2C, pp. 1-40. Edited by D. J. Brenner, N. R. Krieg, J. T. Staley \& G. M. Garrity. New York: Springer.

Gerhardt, P., Murray, R. G. E., Wood, W. A. \& Krieg, N. R. (1994). Methods for General and Molecular Bacteriology. Washington, DC: American Society for Microbiology.

Kimura, M. (1980). A simple method for estimating evolutionary rates of base substitutions through comparative studies of nucleotide sequences. J Mol Evol 16, 111-120.

Kodama, Y., Stiknowati, L. I., Ueki, A., Ueki, K. \& Watanabe, K. (2008). Thalassospira tepidiphila sp. nov., a polycyclic aromatic hydrocarbon-degrading bacterium isolated from seawater. Int J Syst Evol Microbiol 58, 711-715.

Lai, Q., Yuan, J., Gu, L. \& Shao, Z. (2009a). Marispirillum indicum gen. nov., sp. nov., isolated from a deep-sea environment. Int J Syst Evol Microbiol 59, 1278-1281.

Lai, Q., Yuan, J., Wu, C. \& Shao, Z. (2009b). Oceanibaculum indicum gen. nov., sp. nov., isolated from deep seawater of the Indian Ocean. Int J Syst Evol Microbiol 59, 1733-1737.

Lakshmi, K. V. N. S., Sasikala, Ch., Ashok, G. V., Chandrasekaran, R. \& Ramana, Ch. V. (2011). Phaeovibrio sulfidiphilus gen. nov., sp. nov., phototrophic alphaproteobacteria isolated from brackish water. Int $J$ Syst Evol Microbiol 61, 828-833.

Liu, C., Wu, Y., Li, L., Ma, Y. \& Shao, Z. (2007). Thalassospira xiamenensis sp. nov. and Thalassospira profundimaris sp. nov. Int $J$ Syst Evol Microbiol 57, 316-320.

Liu, Y., Jin, J. H., Liu, Y. H., Zhou, Y. G. \& Liu, Z. P. (2010). Dongia mobilis gen. nov., sp. nov., a new member of the family Rhodospirillaceae isolated from a sequencing batch reactor for treatment of malachite green effluent. Int J Syst Evol Microbiol 60, $2780-2785$.

López-López, A., Pujalte, M. J., Benlloch, S., Mata-Roig, M., Rosselló-Mora, R., Garay, E. \& Rodríguez-Valera, F. (2002). Thalassospira lucentensis gen. nov., sp. nov., a new marine member of the $\alpha$-Proteobacteria. Int J Syst Evol Microbiol 52, 1277-1283. 
Mack, E. E., Mandelco, L., Woese, C. R. \& Madigan, M. T. (1993). Rhodospirillum sodomense, sp. nov., a Dead Sea Rhodospirillum species. Arch Microbiol 160, 363-371.

Mattimore, V. \& Battista, J. R. (1996). Radioresistance of Deinococcus radiodurans: functions necessary to survive ionizing radiation are also necessary to survive prolonged desiccation. J Bacteriol 178, 633-637.

Mehnaz, S. \& Lazarovits, G. (2006). Inoculation effects of Pseudomonas putida, Gluconacetobacter azotocaptans, and Azospirillum lipoferum on corn plant growth under greenhouse conditions. Microb Ecol 51, 326-335.

Mesbah, M., Premachandran, U. \& Whitman, W. B. (1989). Precise measurement of the $\mathrm{G}+\mathrm{C}$ content of deoxyribonucleic acid by highperformance liquid chromatography. Int J Syst Bacteriol 39, 159-167.

Pfennig, N., Lünsdorf, H., Süling, J. \& Imhoff, J. F. (1997). Rhodospira trueperi gen. nov., spec. nov., a new phototrophic proteobacterium of the alpha group. Arch Microbiol 168, 39-45.

Rainey, F. A., Ward-Rainey, N., Kroppenstedt, R. M. \& Stackebrandt, E. (1996). The genus Nocardiopsis represents a phylogenetically coherent taxon and a distinct actinomycete lineage: proposal of Nocardiopsaceae fam. nov. Int J Syst Bacteriol 46, 1088-1092.

Saitou, N. \& Nei, M. (1987). The neighbor-joining method: a new method for reconstructing phylogenetic trees. Mol Biol Evol 4, 406-425.

Sghaier, H., Ghedira, K., Benkahla, A. \& Barkallah, I. (2008). Basal DNA repair machinery is subject to positive selection in ionizingradiation-resistant bacteria. BMC Genomics 9, 297.

Sly, L. I. \& Stackebrandt, E. (1999). Description of Skermanella parooensis gen. nov., sp. nov. to accommodate Conglomeromonas largomobilis subsp. parooensis following the transfer of Conglomeromonas largomobilis subsp. largomobilis to the genus Azospirillum. Int J Syst Bacteriol 49, 541-544.

Smibert, R. M. \& Krieg, N. R. (1994). Phenotypic characterization. In Methods for General and Molecular Bacteriology, pp. 611-654. Edited by P. Gerhardt, R. G. E. Murray, W. A. Wood \& N. R. Krieg. Washington, DC: American Society for Microbiology.

Tamura, K., Dudley, J., Nei, M. \& Kumar, S. (2007). MEGA4: molecular evolutionary genetics analysis (MEGA) software version 4.0. Mol Biol Evol 24, 1596-1599.

Tarrand, J. J., Krieg, N. R. \& Döbereiner, J. (1978). A taxonomic study of the Spirillum lipoferum group, with descriptions of a new genus, Azospirillum gen. nov. and two species, Azospirillum lipoferum (Beijerinck) comb. nov. and Azospirillum brasilense sp. nov. Can J Microbiol 24, 967-980.
Thompson, J. D., Gibson, T. J., Plewniak, F., Jeanmougin, F. \& Higgins, D. G. (1997). The CLUSTAL_X windows interface: flexible strategies for multiple sequence alignment aided by quality analysis tools. Nucleic Acids Res 25, 4876-4882.

Urios, L., Michotey, V., Intertaglia, L., Lesongeur, F. \& Lebaron, P. (2008). Nisaea denitrificans gen. nov., sp. nov. and Nisaea nitritireducens sp. nov., two novel members of the class Alphaproteobacteria from the Mediterranean Sea. Int J Syst Evol Microbiol 58, 2336-2341.

Wang, Y. X., Liu, J. H., Zhang, X. X., Chen, Y. G., Wang, Z. G., Chen, Y., Li, Q. Y., Peng, O. \& Cui, X. L. (2009). Fodinicurvata sediminis gen. nov., sp. nov. and Fodinicurvata fenggangensis sp. nov., poly- $\beta$ hydroxybutyrate-producing bacteria in the family Rhodospirillaceae. Int J Syst Evol Microbiol 59, 2575-2581.

Weon, H. Y., Kim, B. Y., Hong, S. B., Joa, J. H., Nam, S. S., Lee, K. H. \& Kwon, S. W. (2007). Skermanella aerolata sp. nov., isolated from air, and emended description of the genus Skermanella. Int J Syst Evol Microbiol 57, 1539-1542.

Wilson, K. (1987). Preparation of genomic DNA from bacteria. In Current Protocols in Molecular Biology, pp. 2.4.1-2.4.2. Edited by F. M. Ausubel, R. Brent, R. E. Kingston, D. D. Moore, J. G. Seidman, J. A. Smith \& K. Struhl. New York: Wiley.

Xie, C. H. \& Yokota, A. (2003). Phylogenetic analyses of Lampropedia hyalina based on the 16S rRNA gene sequence. J Gen Appl Microbiol 49, 345-349.

Xie, C. H. \& Yokota, A. (2005). Azospirillum oryzae sp. nov., a nitrogen-fixing bacterium isolated from the roots of the rice plant Oryza sativa. Int J Syst Evol Microbiol 55, 1435-1438.

Yoon, J. H., Kang, S.-J., Park, S. \& Oh, T.-K. (2007). Caenispirillum bisanense gen. nov., sp. nov., isolated from sludge of a dye works. Int J Syst Evol Microbiol 57, 1217-1221.

Zhang, L., Yang, Q., Luo, X., Fang, C., Zhang, O. \& Tang, Y. (2007). Knockout of crtB or crtI gene blocks the carotenoid biosynthetic pathway in Deinococcus radiodurans $\mathrm{R} 1$ and influences its resistance to oxidative DNA-damaging agents due to change of free radicals scavenging ability. Arch Microbiol 188, 411-419.

Zhang, G. I., Hwang, C. Y. \& Cho, B. C. (2008). Thalassobaculum litoreum gen. nov., sp. nov., a member of the family Rhodospirillaceae isolated from coastal seawater. Int J Syst Evol Microbiol 58, 479485 . 